\title{
The Effect of Quality of Physical Environment, Food and Service on Customer Satisfaction and Behavioral Intentions in Pekanbaru
}

\author{
Sri Restuti \\ Lecturer, Faculty of Economic and Bussiness, University of Riau, \\ Campus Binawidya KM.12,5 Simpang baru, Tampan, Pekanbaru, Riau, Indonesia, 28296
}

\begin{abstract}
This study aimed to determine direct and indirect effect of the three elements of food service quality dimensions which consisted of quality of physical environment, food and service both on customer satisfaction and behavioral intentions based on the Kisang's Model (2012). The data obtained from the distribution of questionnaires to 300 respondents in Pekanbaru, Indonesia. The data were collected bypurposivesampling technique. The data were analyzed by using inferential statistics using path analysis with PLS.The research result showed that directly, thequality of physical environment and food quality had a significant and positive effect on behavioral intentions. However, service quality did not have significant effect onbehavioral intentions. Indirectly,customer satisfaction affected significantly and positively, which means that it mediated between quality of physical environment, food and service of behavioral intentions.
\end{abstract}

Keywords: Physical environment quality, food quality, service quality, customer satisfaction dan behavioral intentions.

DOI: $10.7176 / \mathrm{EJBM} / 11-29-02$

Publication date:October $31^{\text {st }} 2019$

\section{Background of Study}

Restaurant business never dies, even this business is growing along with the development of population and lifestyle. Central Bureau of Statistics (BPS) data showed that in Indonesia over the past 10 years, the average expenditure per capita a month for food and beverages is $51 \%$ of total expenditure.

The growth of restaurants in Indonesia grows along with more people who like to eat in restaurants and become a lifestyle. In Pekanbaru, the average growth for six years in 2015 was $9.28 \%$.

The increasing number of restaurants is caused by the trend of visiting restaurants not only as a biological necessity but as a place for socialization as well. In line with the trends of the culinary industry in Indonesia which presents various unique and delicious food menus, it alsogives variety of attractive offers that increasingly increase consumers' interest to eat outside more.

The growth of restaurants leads to intense competition. Therefore, understanding consumer behavior will facilitate management in efforts to develop products or services according to the needs and desires of consumers. The customer's desire to behave is often based on the likelihood of actions to be taken (behavioral intentions). According to Peter \& Olson (2008) behavioral intention is a proportion which connects itself with future actions.

Customer intentions'behavior towards products and services is the result of the customers' process of satisfaction towards products and services, depending on how much satisfaction the customer feels. Every restaurant must have a strategy to trigger the intention of consumers to choose and visit (post-dining behavioral intention). Customer satisfaction and post-dining behavioral intention are two important things that must be created 
in a restaurant business. Customers who are satisfied with a company's goods/ services will produce long-term profits for the company, including customer loyalty and continuous profit (Homburg et al., 2006).

In the present time, the lifestyle for culinary tour has become part of Indonesian people lifestyle. Now, restaurants do not only provide a variety of food menus, but also pay attention to the place, service, and location as a supporting aspect for the people to choose where to dining place.

According to Consumer Purchasing Priorities survey from MasterCard which was conducted from May and June 2015, 1 in 2 consumers in Indonesia usually made choices on restaurant based on word of mouth and recommendations from friends and family which reached $58 \%$, and $7 \%$ of consumers wrote online comments and reviews about their culinary experiences because of the rapid use of social media in the community. People like to display their photos when they visited good restaurants. For this reason, many restaurants offer different concepts, not only interesting food menus but also the interior and theme of the restaurant which were made as attractive as possible.

Based on the research results of Ryu et al (2012), restaurant service quality which consists of food, physical environment and employees' services must function as important components when dining in restaurants, in order to shape the perception of restaurant's service quality in the restaurant industry.

It is clear that the restaurant business can no longer rely solely on taste and price, because today'sconsumers also pay close attention to the overall dining experience including the physical environment such as interior design and service. In order to survive and develop, a restaurant must have a strategy which makes consumers feel satisfied when visiting and dining the restaurant.

\section{Theoretical Framework and Hypotheses Development}

a. To determine the effect of physical environment quality on behavior intentions.

b. To determine the effect of food quality on behavioral intentions

c. To determine the effect of service quality on behavioral intentions

d. To determine the effect of customer satisfaction on behavioral intentions

e. To determine the effect of physical environment quality on behavioral intentions through customer satisfaction

f. To determine the effect of food quality on behavioral intentions through customer satisfaction.

g. To determine the effect of service quality on behavioral intentions through customer satisfaction.

\section{Review of Literature}

\subsection{Service Quality of a Restaurant}

a restaurant is a place or building that is commercially organized, which provides good service to all guests in the form of food and drink (Marsum, 2005). Generally, restaurantalso present its own uniqueness as attraction, both through the menu, entertainment and physical appearance of the building.

Restaurant is a business aimed for profit, and giving satisfaction to consumers is the main operational purpose of the restaurant. In general, restaurant is a place that people visit to look for various kinds of food and drinks. Restaurants usually also present their own uniqueness as an attraction, both through the menu of cuisine, entertainment and physical appearance of the building.

According to Ryu, et al (2012) several studies indicated that food, physical environment, and employee 
services must function as a vital component of restaurant experience to shape perceptions about the quality of restaurant service in the restaurant industry. Food, service and atmosphere are the most common attributes in restaurant quality.

\subsection{Physical Environment Quality}

Characteristics in the service industry are called service marketing mix, which is divided into 7Ps, namely product, promotion, place, price, process, people, and physical evidence. Each of the seven elements of the marketing mix are interconnected with each other, and have an optimal marketing mix based on the characteristics of the segments (Tjiptono and Chandra, 2011).

Physical evidence of the market industry is a place or environment where services are provided, interactions between service providers and consumers take place, and/ or a place where all commodities or facilities can be clearly received by the five senses of consumer (Zeithmal, 2004). In general, the place where products and services are provided or consumed is the most influencingfactor for customer satisfaction.

Because services are not physically visible, customer satisfaction and evaluation of services generally are received based on more tangible aspect, which is physical evidence. The environmental element is the customer's interaction with intangible and tangible elements in a service environment (for example: lighting, music, internal and external design of the service environment) or the period of time when the customer interacts with physical facilities or with non-physical facilities in the service environment (Bitner, 1990), in which it is also explained that physical evidence can influence consumer behavior. In this study, the physical evidence term refers to the physical environment.

Physical evidence is the physical environment of the company where the service was created and where the service providers and consumers make interaction, added by any tangible elements used to communicate or support the role of the service. In the service business, it is offered by the company in order to support the positioning and image, as well as increasing the scope of products.

The convenience of the location is the most important thing in marketing. When consumers come to service providers, they expect a situation that is easily obtained, used, and supported by the patient staffs. Manyservices companies provide specificity or distinctiveness that distinguishes them from competitors.

In general, the dimensions of the restaurant service environment are divided into three major groups (RambatLupiyoadi, 2013), which are exterior facilities, general interiors, and store layout. The physical environment is defined as all elements in a service area which can be captured by the five senses and can be controlled or shaped by human hands. The physical environment can be sensed through the five senses in the form of sight (light, color, shape, size, sound, smell and touch (temperature, tenderness, smoothness). Sense of tasting (tongue) is not directly used to capture or feel the atmosphere

\subsection{Food Quality}

Food quality is considered as a very important dimension of restaurant quality because it is the most important attribute of restaurant quality and a predictor key of customer loyalty. It has also been shown that food quality has a positive effect on the customer's dining experience and is very important for the success (Ryu, et al., 2012). Food quality is one of the main factors why customers choose to visit a restaurant. Among various attributes of food 
quality, taste of the food is one of the most important criteria for customers. Choosing a restaurant because of its delicious food gives consumers a positive sense of experience and emotional satisfaction during their dining experience. Moreover, with increasing public attention to healthy lifestyles, food quality is not only the taste of food but also nutrition and food safety issues (Ryu and Han, 2010).

According to Marsum (2005), several things that must be applied in food quality includesflavor, consistency, texture/ form/ shape, nutritional content, visual appeal, aromatic appeal, and temperature.

When the restaurant does the 7 things above, then the restaurant can fulfill the tastes of customers and can make quality food. Consistency of food quality from the restaurant can make customers satisfied and loyal to the restaurant.

\subsection{Service Quality}

In the service business, attitudes and contact personnel are crucial elements which have a significant effect on the quality of services givento the customers. The way the employees give satisfactory serviceto customers plays an important role in creating service excellence. Service excellence can only be created if there are the integration of the four pillars which are speed, accuracy, friendliness and comfort (Tjiptono and Chandra, 2011). In the restaurant industry,service quality is as important as food quality and plays an important role in creating customer quality, patronization and positive perceptions about restaurant and dining experience.

Service quality depends on the emotional side of customers, in terms of quality and interaction between customers and service providers. Employee service behavior is an important factor for assessing service quality. According to Zeithaml in Chang \& Chen (2008), service quality has a very strong impact on consumer behavior such assatisfaction with company products, willingness to pay more, and unwillingness to move to other products.

\subsection{Customer Satisfaction}

According to Kotler and Keller (2009), satisfaction is someone's happiness or disappointment that happen due to comparing the perceived performance of the product (or results) against their expectations. If the performance does not meet expectations, the customer will not be satisfied. If the performance is suitable with expectations, the customer will be satisfied. If performance exceeds expectations, the customer will be very satisfied or happy. Customer assessment of product performance depends on many factors, especially the relation type of customer loyalty with the brand. Consumers often form more favorable perceptions of a product with a brand that they already feel positive about.

According to Walker, et al. (2001),customer satisfaction can be defined as a situation where the customers' needs, desires, and expectations can be fulfilled through the products consumed. In general, customer satisfaction can be considered as pleasure or disappointment resulted from comparing the products purchased with the initial expectations. According to Tjiptono and Chandra (2011), customer satisfaction or dissatisfaction is the customer's response to the evaluation of perceived disconfirmation between initial expectations or other performance expectations and the actual performance of the product give after making use of it.

Based on several definitions above,customer satisfaction is anexpectationfulfillment. Customer is categorized as satisfiedwith the product or service provided by the restaurant if their expectations of the product/ service is suitable, even exceed, their expectations. In the service industry, customer satisfaction is measured based on overall 
experience with the company.

\subsection{Behavioral Intentions}

Behavioral intentions of products and services are the result of the process of satisfaction experienced by customers, for products and services from the providers. Customer satisfaction to the products and services can be a high or lowdepends on the level ofcustomer satisfaction. Understanding of consumer behavior will facilitate management in efforts to develop products or services according to the needs and desires of consumers. The consumer desire to behave is often based on the possibility of action to be taken.

According to Schiffman and Kanuk (2010), behavioral intention is the purchasefrequency or the proportion of total purchases from buyers who are loyal to a particular brand. Buyers can be considered as loyal to a product from their behavior to the product. According to Mowen (2012), behavioral intentions are consumers desire to behave in certain ways in order to own, dispose and use any products or services.

Behavioral intentions can be used as a signal to service provider whether the customes want to continue to establish relationships with service provider. Zeithaml (2004) defines behavioral intentions as a willingness to recommend services to others, and a willingness to repurchase. Behavioral intentions can be seen as indicator which become a sign for situation where a customer wants to remain a customer or leave the company which give service.

\section{Hypothesis}

a. There is significant effect between quality of physical environment on behavioral intentions.

b. There is a significant effect between food quality on behavioral intentions

c. There is a significant effect between service quality on behavioral intentions.

d. There is a significant effect between customer satisfaction on behavioral intentions

e. There is a significant effect between physical environment quality on behavioral intentions through customer satisfaction

f. There is a significant effect between food quality on behavioral intentions through customer satisfaction

g. There is a significant effect between service quality on behavioral intentions through customer satisfaction

\section{Research Method}

This As The population of the study were individuals who visited and enjoyed food in restaurants. The sample of this study was 300 people. The data used are primary data taken by questionnaire. The data was collected bypurposive sampling technique. Data analysis in this study was done by inferential statistics with 5 (five) variables using Path Analysis with PLS.

\section{Research Variable}

This study was carried out based on indicators in the Kisang's Model in Ryu, et al (2012), where exogenous variables consist of physical environment quality, food quality, and service quality.

Quality of physical environment indicators consisted of the restaurant which had attractive interior design and decor, pleasing background music, clean and thorough dining area, and neat and well-dressed employees. 
Food quality indicators were food was delicious, fresh and nutritious, menu items offered was varied, the smell of the food was enticing and the food presentation was visually attractive.

Restaurant service indicators werethe employees served the foodexactly like the order, provided prompt and quick service, always willing to help the customer, and who made the customer comfortable in dealing with them.

Endogenous variables in this study consisted of two variables, namely customer satisfaction and behavioral intentions. The customer satisfaction indicatorwas the customer who was satisfied with the overall experience at this restaurant, puts them in a good mood and enjoyed themselves at the restaurant.

Other endogenous variables are behavioral intentions consisted of the customer preference to come back and revisit the restaurant in the future, recommend this restaurant to friends or others, and say positive things about this restaurant to others and encourage others to visit the restaurant.

\section{Result and Discussion}

\subsection{Research Instrument Testing}

The research instrument testing consisted of two tests, namely the reliability test and the validity test. From the test results, it was obtained that all constructs had Cronbach Alpha $(\alpha)>0.60$, so it was considered that all constructs were reliable.

The validity test of the research instrument showed that the value of $r$ count $>r$ table $(0.113)$ and was positive, so it can be stated that all indicators used in this study were valid.

\subsection{Result of Analysis}

\subsubsection{Goodness of Fit inWarpPLS}

Based on the test result, it was found that the predictive-relevance value was 0.5767 or $57.67 \%$, so that the model was feasible because it had a relevant predictive value. Predictive relevance value of the results of the study was $57.67 \%$ which showed Goodness of Fit testing by using predictive-relevance (Q2) value. The R2 value of each endogenous variable in this study were 0.49 for the customer satisfaction (CS) variable and 0.17 for the behavioral intentions (BI) variable. Predictive-relevance value was obtained with the formula of:

$\mathrm{Q} 2=1-(1-\mathrm{R} 12)(1-\mathrm{R} 22)$

$\mathrm{Q} 2=1-(1-0.49)(1-0.17)=0,5767=57.67 \%$

in which the diversity of data from exogenous variables which could be explained by the model was $57.67 \%$. In other words, the information contained in the $57.67 \%$ data could be explained by the model. Whereas, the rest was explained by other variables (which were contained in the model yet) and error.

\subsubsection{Hypothesis Testing inInner Model: Direct Effect}

The testing result of the inner model (structural model) basically tested the hypothesis in the study. Hypothesis testing was done by t-test (T-Statistic) on each path of direct influence partially. The results of the complete analysis were shown in the PLS analysis results, which can be seen in Table 1 below which presented the result of direct influence hypothesis testing.quality. 
Tabel 1 Hypothesis Testing Result In The Inner Model: Direct Effect

\begin{tabular}{|l|l|l|c|}
\hline \hline \multicolumn{1}{|c|}{ Correlation } & \multicolumn{1}{c|}{$\begin{array}{c}\text { Path } \\
\text { Coefficient }\end{array}$} & $\begin{array}{c}\text { p- } \\
\text { value }\end{array}$ & Explanation \\
\hline $\begin{array}{l}\text { Quality of physical environment(QPE) } \rightarrow \text { Behavioral Intentions } \\
(\mathrm{BI})\end{array}$ & 0.20 & $<0.01$ & Significant \\
\hline Food Quality (FQ) $\rightarrow$ Behavioral Intentions (BI) & 0.11 & 0.02 & Significant \\
\hline Service Quality (SQ) $\rightarrow$ Behavioral Intentions (BI) & 0.02 & 0.38 & $\begin{array}{c}\text { Not } \\
\text { Significant }\end{array}$ \\
\hline Customer Satisfaction(CS) $\rightarrow$ Behavioral Intentions (BI) & 0.20 & $<0.01$ & Significant \\
\hline
\end{tabular}

Source: Processed Data

The analysis results obtained by the Path Analysis model which described the correlation between direct and indirect variables is shown below:

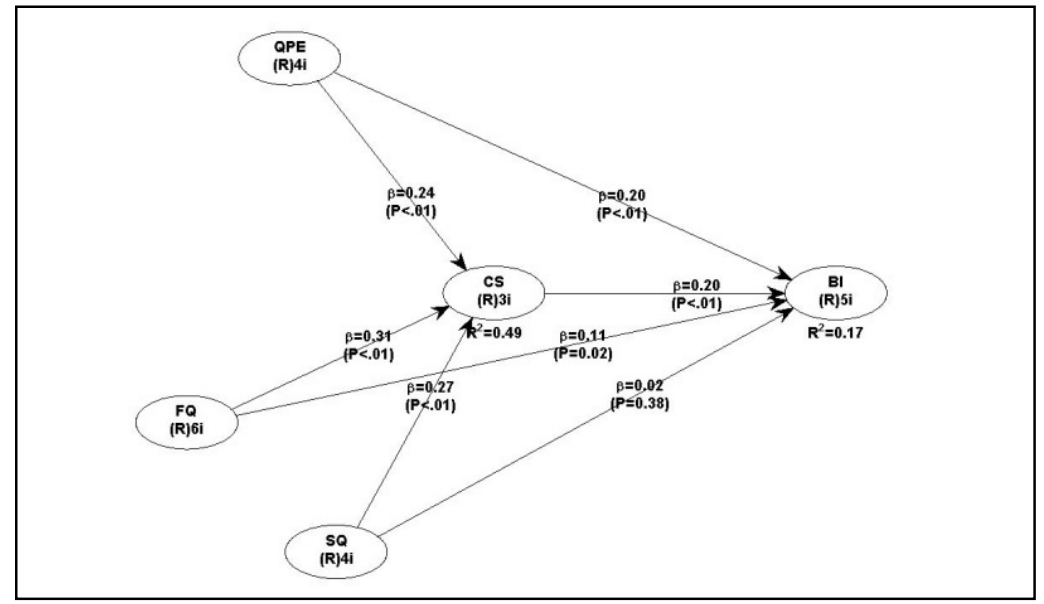

Fig. 1. Path Diagram of Hypothesis Testing

From the test result above, it can be concluded as follows:

1. Testing on the direct effect between Quality of Physical Environment (QPE) on Behavioral Intentions, an inner weight coefficient value obtainedwas 0.20 , with a p-value of $<0.01$. Because the $p$-value was $<0.05$, there was a significant direct effect between Quality of Physical Environment (QPE) on Behavioral Intentions, and there was a positive relationship between them. This showed that the better the Quality of Physical Environment delivered, the bigger the desire of consumers to re visit the restaurant.

2. Testing on the direct effect between Food quality on Behavioral Intentions obtained an inner weight coefficient of 0.11 with a p-value of 0.02 . Because the $p$-value was $<0.05$, there was a significant direct effect between Food quality on Behavioral Intentions and there was a positive correlation. It means that the food quality, such as food delicacy, food nutrition, menu variations, freshness, aroma of food and attractive presentation, affected the desire of consumers to come back to the restaurant.

3. Testing on the direct effect between Service Quality on Behavioral Intentions obtained inner coefficient value of 0.02 with a p-value of 0.38 . Because p-value was $>0.05$, there was no significant direct effect between Service Quality on Behavioral Intentions. This means that the better service quality the higher the desire of consumers to revisit it. However, this effect was not significant increase the desire to revisit the 
restaurant.below:

7.2.3 Hypothesis Testing inInner Model: Indirect Effect

In addition to testing the direct effect, also an indirect effect testing was also done. The indirect effect was considered significant if the two or more direct effects that formed itwere significant. The result of indirect effect is shown as follows:

Tabel 2 Result of Hypothesis Testing in Inner Model: Indirect Effect

\begin{tabular}{|l|l|l|l|l|}
\hline \hline Indirect Effect & \multicolumn{2}{|l|}{ Direct Effect Coefficient } & Indirect Effect Coefficient & Significance \\
\hline QPE $\rightarrow$ CS $\rightarrow$ BI & QPE $\rightarrow$ CS & $\begin{array}{l}\text { CS } \rightarrow \text { BI } \\
0,20(\mathrm{Sig})\end{array}$ & 0.048 & Significant \\
\hline FQ $\rightarrow$ CS $\rightarrow$ BI & FQ $\rightarrow$ CS & CS $\rightarrow$ BI & 0.062 & Significant \\
& $0.31(\mathrm{Sig})$ & $0.20(\mathrm{Sig})$ & & \\
\hline SQ $\rightarrow$ CS $\rightarrow$ BI & SQ $\rightarrow$ CS & CS $\rightarrow$ BI & 0.054 & Significant \\
& $0.27(\mathrm{Sig})$ & $0.20(\mathrm{Sig})$ & & \\
\hline
\end{tabular}

Source: Processed Data

Based on Table 2, there were 3 indirect effect. The complete result is explained as follows:

1. The indirect effect between Quality of Physical Environment on Behavioral Intentions through Customer satisfaction was 0.048 . The direct effect of Quality of Physical Environment on Customer satisfaction was 0.24 with p-value $<0.01$ and the direct effect between Customer Satisfaction on Behavioral Intentions was 0.20 which was significant with $p$-value of $<0.01$. It can be concluded that the relationship of Quality of Physical Environment to Behavioral Intentions through Customer Satisfaction was significant.

2. The indirect effect between Food Quality on Behavioral Intentions through Customer Satisfaction obtained a coefficient of 0.062 with a significant effect. It was caused by the direct effect of food quality on Customer Satisfaction of 0.31 with a significant $\mathrm{p}$-value $<0.01$, while the direct effect between Customer Satisfaction on behavioral intentions was 0.20 with a p-value of $<0.01$. It can be concluded that the influence of Food quality on behavioral intentions through Customer Satisfaction was significant.

3. The indirect effect coefficient was 0.054 which was significant, because the direct effect of Service Quality on Customer Satisfaction was 0.27 ; significant with $\mathrm{p}$-value $<0.01$. The direct effect between Customer Satisfaction on Behavioral Intentions of 0.20 was significant with $p$-value of $<0.01$. It can be concluded that the relationship between Service Quality and Behavioral Intentions through Customer Satisfaction was significant.

\subsubsection{Discussion}

1. Effect of Quality of Physical Environment on Behavioral Intentions

Based on the results of the study, the Quality of Physical Environment had a positive and significant effect on intention behavior. It means that the Quality of Physical Environment could increase the consumerdesire to revisit to the restaurant. It was caused by the neat appearance of employees and attractive restaurant interior design, so that the consumerdesire to come back is even higher. This finding is reinforced by the results of AlTit's (2015) study which stated that some tangible dimensions which are identical to the restaurant'sphysical facilities have significant and positive influence on Customer Retention.

2. Effect of Food Quality on Behavioral Intentions 
This study found that Food Quality had a positive and significant effect on behavioral intentions. This result is in line with Bujisic et al. (2014) that food quality has a linear and positive relationship with Behavioral Intention (return intentions and word of mouth). It shows that Food Quality can increase the consumer desire to revisit the restaurant. Delicious and nutritious food, variety of food, fresh food ingredients, aroma and attractive presentation can attract consumers to return to the restaurant.

3. Effect of Service Quality on Behavioral Intentions

Based on the results of the study, it was found that there was no significant direct effect between Service Quality and Behavioral Intentions, but it was directed to positive correlation. It means that good service quality can increase the consumerdesire to come back to the restaurant, but the effect is not significant. It was caused bysome food was not givenbased on the order, slow service, employees who were less responsive to complaints andunfriendly. It gave impact to Service Quality which was considered to not optimum yet. It also stated by Bujisic et al (2014) that there is no linear relationship either in quick service restaurants or in upscale restaurants to Customer behavioral intentions (return intentions and word of mouth).

4. Direct effect ofCustomer Satisfaction on Behavioral Intentions

This study found that direct effect between Customer Satisfaction and Behavioral Intentions was significantly positive. This means that more satisfiedconsumers can increase their interest to come back to visit the restaurant. Satisfaction in this term related to the pleasant experience they have felt, the mood shifting of visitors to be happy and joyful in the restaurant. The more the restaurant is able to givesatisfaction, the higher the possibility of the consumer to come back. Significantinfluence of Customer Satisfaction on Behavioral Intentions is also found in the results of research by Ryu et al. (2011), and Haery and Badiezadeh (2014) that Customer Satisfaction has a significant effect on Behavioral Intentions or post-purchase behavior.

5. Indirect effect of Quality of Physical Environment onBehavior Intentions through Customer Satisfaction This study found that the Quality of Physical Environment indirectly had a significant effect on Behavioral Intentions through Customer Satisfaction. It means that an increase in the Quality of Physical Environment can improve Customer Satisfaction, which can increase interest in visiting the restaurant again. In other words, Customer Satisfaction can mediate the influence of Quality of Physical Environment on Behavioral Intentions.It is in line with Al-Tit's study (2015) that Customer Satisfaction mediates the relationship between Service Quality (tangible dimension) and Customer Retention.

6. Indirect effect ofFood Quality on behavioral Intentions through Customer Satisfaction

The results showed that the effect of Food Quality indirectly had a significant effect on Behavioral Intentions through Customer Satisfaction. It means that the better Food Quality cause the higher Customer Satisfaction, so the desire to come back to the restaurant is stronger. Itis because Food Quality which includes delicacy of food, food nutrition, variety of menus, freshness, aroma of food and interesting presentation affect the desire of consumers to come back to the restaurant. It can also be considered that Customer Satisfaction is able to mediate the influence of Food Quality on Behavior Intention. Namkung and Jang (2007) also found that there is a significant effect of Food Quality on behavioral intention through Customer Satisfaction.

7. Indirect effect of Service Quality on Behavioral Intentions throught Customer Satisfaction

This study found that the influence of Service Quality indirectly had a positive and significant effect on Behavioral Intentions through Customer Satisfaction. It means that good Service Quality which consists of the 
ability of employees to deliver food on order, quickly and precisely, who give fast response to customer complaints and friendly are able to increase Customer Satisfaction. Thus, it has an impact on increasing the desire of consumers to return to restaurants. In other words, Customer Satisfaction is able to mediate the effect of Service Quality on Behavioral Intentions. This is in line with the results of Canny's (2013) study that Service Quality affects both Customer Satisfaction and Behavioral Intention. Al-Tit (1015) also found that Customer satisfaction mediates Service Quality with Customer.

\section{Conclusion}

Based on the results of the study, it can be concluded as follows:

1. Quality of Physical Environment and Food Quality significantly influence Behavioral Intentions.

2. Service quality directly does not significantly influence Behavioral Intentions.

3. Quality of Physical Environment, Food Quality and Service Quality indirectly give significant influence Behavioral Intention through Customer Satisfaction.

\section{Suggestion}

Quality of Physical Environment and Food Quality significantly influence Customer Satisfaction and Behavioral Intentions. The indicators that create the two variables must be improved, especially those which are considered to be lacked of by consumers. Increased customer satisfaction will increase the desire of consumers to return to the restaurant and even recommend it to others. The management of the restaurant must be able to make consumers feel enjoy being in the restaurant. Regarding the Quality of Physical Environment, the music played and the clothes worn by restaurant employees turns out to be a concern of consumers, and the customers think that the restaurant pays little attention to it. Related to Food Quality, it is very important for restaurant managers to pay attention to the appearance of the food presentation, including the cleanliness of the tools used. Although Service Quality does not have a significant effect on Behavioral Intention, but it affects Customer Satisfaction because service is the key to the marketing. Therefore, restaurant managers must also improve the ability of employees to serve customers quickly,do no errors in delivering orders and be responsive whenever there are complaints for the services provided.

\section{References}

Al-Tit, A A (2015), The Effect of Service and Food Quality on Customer Satisfaction and Hence Customer Retention, Asian Social Science, Volume:11, No: 23, 2015.

Ara, A \&Zargar, A.S, (2018), An Empirical Study of the Impact of ServiceQuality on Customer Satisfaction and Repurchase Intention in Hotels of Northern India, International Journal of Trend in Scientific Research and Development (IJTSRD), Volume 2, issue 3.

Bitner, M.J (1990). Evaluating Service Encounters: The Effects of PhysicalSurroundings and Employee Responses. Journal of Marketing. Vol. 54, No.2, pp. 69-82.

Bujisic,M , et al (2014), The effects of restaurant quality attributes on customer behavioral intentions,International Journal of Contemporary Hospitality Management, Volume: 26 No. 8, pp: 1270 - 1291.

Canny, I,U, (2013), The Role of Food quality, service Quality and Physical Environment on Customer Satisfaction 
and Future Behavioral Intentions in Casual Dining Restaurant, Konferensi Nasional RisetManajemen VII Palembang, 27 November 2013, ISSN: 2086-0390 .

Chang, Tung-Zong\&Su-Jane Chen, 2008, "Market Orientation, Service Quality and Business Perfomance: a Conceptual Model and Empirical Evidence”, Journal of Service Marketing, Vol.12, No.4

Chow, et al (2007), Service quality in restaurant operations in China: Decision- and experiential-oriented perspectives, International Journal of Hospitality Management , 26(3):698-710 •

Haery, F, A \&Badiezadeh, M (2014), Studying the Effect of Food QualityDimensions (Physical Environment, Food and Services) on MentalImage of the Restaurant and Customers' Satisfaction and Intentionsbased on Kisang's Model,International Journal of academic research in Business and Social Sciences,Volume: 4 No: 7.

Homburg, Koschate, \& Hoyer (2006) The Role of Cognition and Affect in the Formation of Customer Satisfaction:

A Dynamic Perspective, Journal of Marketing, Vol. 70, No. 3 2006, pp. 21-31.

Kotler, P \& Keller. (2009), Marketing Management, 13th Edition, Pearson Prentice Hall.

Lupiyoadi, Rambat. (2013). ManajemenPemasaranJasa. Edisiketiga. Jakarta: SalembaEmpat.

Marsum (2005). Restoran dan SegalaPermasalahannya. Yogyakarta: Andi.

Mowen, John C., \& Minor, Michael. (2002). PerilakuKonsumenJilid I Edisi 5 Translated by Lina Salim.Erlangga: Jakarta.

Namkung, Y \&Jang, S. (2007), Does Food Quality Really Matter in Restaurants? Its Impact on Customer Satisfaction and Behavior Intentions, Journal of Hospitality \& Tourism Research 31(3):387-409.

Namkung,Y\&Jang, S. (2008) , Are highly satisfied restaurant customers really different? A quality perception perspective, International Journal of Contemporary Hospitality Management, ISSN: 0959-6119.

Peter, J. P., \& Olson, J. C. (2008). Consumer behavior and marketing strategy (8th ed.). Singapore: McGraw-Hill.

Ryu, K \& Han, Heesup (2010), Influence of Physical Environment on Disconfirmation, Customer Satisfaction, and Customer Loyalty for First-time and repeat Customers in Upscale Restaurants. International CHRIE Conference- Refereed Track, 2010.

Ryu, K., Lee, H \& Kim, W.G.(2012), The influence of the quality of the physical environment, food, and service on restaurant image, customer perceived value, customer satisfaction, and behavioral intentions, International Journalof Contemporary Hospitality Management, Volume: 24 Issue: 2 2012, ISSN200-223.

Schiffman, L., \&Kanuk, L.L. (2010). Consumer Behavior. 10th Edition. New Jersey: Pearson Prentice Hall.

Tjiptono, F \& Chandra. 2011. Service, quality satisfaction. Third Eition. Yogyakarta: Andi.

Walker et al, 2001. Managing Customer Dissatisfaction Through Effective Complaint Management System. Journal of Management Strategy, page 331-335.

Zeithaml,V.A\&Parasuraman,A. Service Quality, 2004. Marketing Science Institute. 